\title{
Cardiorespiratory monitoring of red blood cell transfusions in preterm infants
}

\author{
Jarinda A. Poppe ${ }^{1}$ (I) $\cdot$ Tanja van Essen $^{1} \cdot$ Willem van Weteringen $^{1,2} \cdot$ Sten P. Willemsen ${ }^{1,3} \cdot$ Irwin K. M. Reiss $^{1}$. \\ Sinno H. P. Simons ${ }^{1} \cdot$ Rogier C. J. de Jonge ${ }^{4}$
}

Received: 10 March 2021 / Revised: 19 July 2021 / Accepted: 20 July 2021 / Published online: 9 August 2021

(c) The Author(s) 2021

\begin{abstract}
Clinical improvement after red blood cell (RBC) transfusions in preterm infants remains debated. This study aims to investigate the effect of RBC transfusion on the occurrence of desaturations and hypoxia, and other cardiorespiratory outcomes in preterm infants. In this longitudinal observational study, prospectively stored cardiorespiratory parameters of preterm infants who received at least one RBC transfusion between July 2016 and June 2017 were retrospectively analyzed. Sixty infants with 112 RBC transfusions, median GA of 26.7 weeks, were included. The number of desaturations and area $<80 \% \mathrm{SpO}_{2}$ limit, as a measure of the hypoxic burden, were calculated in $24 \mathrm{~h}$ before and after RBC transfusion. A mixed effects model was used to account for repeated measurements. Overall, the mean (SE) number of desaturations per hour decreased from $3.28(0.55)$ to $2.25(0.38 ; p<0.001)$, and area $<80 \% \mathrm{SpO}_{2}$ limit decreased from $0.14(0.04)$ to $0.08(0.02) \% / \mathrm{s}(p=0.02)$. These outcomes were stratified for the number of desaturations in $24 \mathrm{~h}$ prior to RBC transfusion. The largest effect was observed in the group with the highest mean number of desaturations $(\geq 6)$ prior to RBC transfusion, with a decrease from $7.50(0.66)$ to $4.26(0.38)(p<0.001)$ in the number of desaturations and $0.46(0.13)$ to $0.20(0.06)$ in the area $<80 \% \mathrm{SpO}_{2}$. Perfusion index increased significantly after RBC transfusion $(p<0.001)$. No other significant effects of RBC transfusion on cardiorespiratory data were observed.

Conclusions: RBC transfusions in preterm newborns could help decrease the incidence of desaturations and the area $<80 \%$ $\mathrm{SpO}_{2}$ as a measure of the hypoxic burden. The higher the number of desaturations prior to the RBC transfusion, the larger the effect observed.
\end{abstract}

\section{What is Known:}

-Red blood cell transfusions potentially prevent hypoxia in anemic preterm infants by increasing the circulatory hemoglobin concentration and improving tissue oxygenation.

-There is not a predefined hemoglobin concentration cut-off for the occurrence of symptomatic anemia in preterm infants.

What is New:

- Oxygen desaturations and hypoxia in anemic preterm infants can be improved by RBC transfusions, especially if more desaturations have occurred before transfusion.

- Cardiorespiratory monitor data may help identify infants who will benefit most from red blood cell transfusions.

Keywords Red blood cell transfusion $\cdot$ Vital signs $\cdot$ Preterm infants $\cdot$ Hypoxia $\cdot$ Clinical decision-making

\begin{tabular}{|c|c|c|}
\hline & \multicolumn{2}{|c|}{ Abbreviations } \\
\hline & $\mathrm{FiO}_{2}$ & Fraction of inspired oxygen \\
\hline Communicated by Daniele De Luca & GA & Gestational age \\
\hline \multirow{3}{*}{$\begin{array}{l}\text { Jarinda A. Poppe and Tanja van Essen are contributed equally to } \\
\text { this work }\end{array}$} & $\mathrm{Hb}$ & Hemoglobin \\
\hline & $\mathrm{Ht}$ & Hematocrit \\
\hline & IQR & Interquartile range \\
\hline \multirow{2}{*}{$\begin{array}{l}\triangle \text { Jarinda A. Poppe } \\
\text { j.poppe@ erasmusmc.nl }\end{array}$} & MAP & Mean airway pressure \\
\hline & NICU & Neonatal intensive care unit \\
\hline Extended author information available on the last page of the article & $\mathrm{RBC}$ & Red blood cell \\
\hline
\end{tabular}


$\begin{array}{ll}\mathrm{SE} & \text { Standard error } \\ \mathrm{SpO}_{2} & \text { Oxygen saturation }\end{array}$

\section{Introduction}

Preterm infants often become anemic in the first weeks after birth and may require red blood cell (RBC) transfusion. A study found that the incidence of RBC transfusion is inversely correlated to birth weight with $25 \%$ to $82 \%$ of very low birth weight infants receiving at least one RBC transfusion [1]. Anemia in preterm infants is associated with an increased occurrence of apnea. A possible cause is decreased oxygen transport capacity to the central nervous system followed by lower efferent output of the respiratory center, thus resulting in central apneas [2]. Anemic patients receive RBC transfusions to prevent hypoxia by increasing circulatory hemoglobin ( $\mathrm{Hb})$ and improving tissue oxygenation.

Despite extensive research, the optimal RBC transfusion policy for preterm infants remains unclear [3, 4]. Although some studies found transfusions to be effective in preventing apneas and reducing intermittent hypoxia on the short term, several other studies reported minimal or no effect [5-10]. Additionally, retrospective studies found that RBC transfusions in preterm infants were associated with an increased incidence of intra-hospital mortality, intraventricular hemorrhage, and necrotizing enterocolitis [11-16]. A systematic review concluded, however, that no difference in mortality and severe morbidity at hospital discharge was found in clinical trials comparing liberal to restrictive transfusion strategy [17]. Two recent RCTs reported in addition no difference between liberal and restrictive transfusion strategies in death and/or neurodevelopmental impairment in the long term $[18,19]$.

Identifying those individual patients who will benefit from RBC transfusion remains difficult. Various potential indicators, such as peripheral fractional oxygen extraction, cerebral regional saturation, lactic acid, and vascular endothelial growth factor, have been described [20-23]. According to an international survey, the degree of oxygen requirement and the need for respiratory support are important determinants for the need for transfusion [24]. Although patients are monitored continuously during intensive care admission, only a snapshot of this information is presented to clinicians at the bedside. Visualizing and analyzing these trend data could improve the assessment of medical interventions.

We hypothesized that RBC transfusion decrease the incidence of desaturations and hypoxia in preterm infants and explored this hypothesis by analyzing cardiorespiratory monitor data for different gestational ages (GA), types of respiratory support, and hematocrit $(\mathrm{Ht})$ values before transfusion. Additionally, we evaluated the effect of $\mathrm{RBC}$ transfusion on fraction of inspired oxygen $\left(\mathrm{FiO}_{2}\right)$, heart rate, respiratory rate, perfusion index, and blood pressure.

\section{Materials and methods}

\section{Study design and population}

In this longitudinal observational study, prospectively stored physiological data were analyzed in retrospect. Preterm infants who received at least one RBC transfusion between July 2016 and June 2017 at the neonatal intensive care unit (NICU) of the Erasmus MC Sophia Children's Hospital were eligible for inclusion. We excluded data when patients had received an exchange transfusion for hyperbilirubinemia, had been diagnosed with hemolytic anemia, or had died within $24 \mathrm{~h}$ after birth. Additionally, individual transfusions administered during surgery, within $24 \mathrm{~h}$ after birth, or with a follow-up duration of less than $24 \mathrm{~h}$ were excluded. The local medical ethics review board waived approval for this study pursuant to the Dutch Medical Research Involving Human Subjects Act (MEC-2018-1106).

\section{Data acquisition}

Baseline characteristics and pre-transfusion laboratory results were collected from the electronic medical records (HiX version 6.1, Chipsoft, Amsterdam, Netherlands). Small for gestational age was calculated according to Fenton and Kim [25]. The administered volume of blood, the ventilation mode, caffeine therapy, and $\mathrm{FiO}_{2}$ were collected from the electronic patient data management system (PICIS, Wakefield, MA). Continuously logged physiological data $(1 \mathrm{~Hz})$, automatically collected from bedside monitors (Dräger Infinity ${ }^{\circledR}$ M540, Dräger, Lübeck, Germany) from $72 \mathrm{~h}$ before until $72 \mathrm{~h}$ after RBC transfusion, included peripheral oxygen saturation $\left(\mathrm{SpO}_{2}\right)$, heart rate, respiratory rate, arterial blood pressure, and perfusion index.

\section{Transfusion protocol}

A RBC transfusion of $15 \mathrm{ml} / \mathrm{kg}$ was administered during $4 \mathrm{~h}$ following the local protocol. From $24 \mathrm{~h}$ after birth, transfusion was indicated in patients without clinical symptoms and $\mathrm{Ht}<18 \%$. Patients with clinical symptoms were transfused at $\mathrm{Ht} \leq 30 \%$ in case of mean airway pressure (MAP) $\geq 8 \mathrm{~cm}$ 
$\mathrm{H}_{2} \mathrm{O}$ and/or $\mathrm{FiO}_{2} \geq 0.4$; at $\mathrm{Ht} \leq 25 \%$ for $\mathrm{MAP}<8 \mathrm{~cm} \mathrm{H}_{2} \mathrm{O}$ and/or $\mathrm{FiO}_{2}<0.4$, NIPPV, or CPAP $\geq 6 \mathrm{~cm} \mathrm{H} \mathrm{H}_{2} \mathrm{O}$; and at $\mathrm{Ht} \leq 20 \%$, for CPAP $<6 \mathrm{~cm} \mathrm{H}_{2} \mathrm{O}$. Clinical symptoms were defined as recurrent apneas or bradycardia, increased oxygen need, increased heart rate or respiratory rate during $24 \mathrm{~h}$, and insufficient growth.

\section{Outcome measures}

The primary outcomes are the number of desaturations below an $80 \% \mathrm{SpO}_{2}$ limit and the area under the $80 \% \mathrm{SpO}_{2}$ limit as a measure of the hypoxic burden. The limit of $80 \%$ was based on the previous data by Poets et al. [26]. The area under the $80 \% \mathrm{SpO}_{2}$ limit was calculated by multiplying the difference between the $\mathrm{SpO}_{2}$ limit and the measured $\mathrm{SpO}_{2}$ by the time spent below the $\mathrm{SpO}_{2}$ limit, expressed as percent per second (Fig. 1). Secondary outcomes are the $\mathrm{FiO}_{2}$, $\mathrm{SpO}_{2}$, heart rate, respiratory rate, arterial blood pressure, and perfusion index.

Different subgroups were defined. One is based on the mean number of desaturations in the $24 \mathrm{~h}$ before transfusion start, classified as desaturations $\leq 1$, desaturations $1-3$, desaturations $3-6$, and desaturations $\geq 6$. Other subgroups were based on GA classified as GA $<26$ weeks, GA 26-28 weeks, and GA $\geq 28$ weeks, respiratory support at start of transfusion, invasive versus non-invasive, and $\mathrm{Ht}$ values prior to transfusion, classified as $\mathrm{Ht}<25 \%$, Ht 25-30\%, and $\mathrm{Ht} \geq 30 \%$.

\section{Data processing}

Measurements marked as invalid by the bedside monitors were excluded. The number of desaturations and the area under the $80 \% \mathrm{SpO}_{2}$ limit were calculated per hour using LabVIEW (version 2018 SP1, National Instruments, Austin, TX, USA). We preprocessed the secondary outcomes by calculating the median per transfusion for every hour. Data were visualized hourly in median [interquartile range (IQR)] per desaturation subgroup for the primary outcomes and for all transfusions for the secondary outcomes. Data that overlapped with data from the analysis period of an earlier transfusion were excluded from the analysis.

\section{Statistical analysis}

Baseline characteristics are expressed as median [IQR] for continuous variables and as number (\%) in categorical variables. Mixed effects models were used in the $24 \mathrm{~h}$ before and after RBC transfusion to analyze the effect of transfusion on the outcome of interest with adjustment for repeated measurements. A Poisson mixed effects model was used for count data. Log transformation was applied in case of non-normality of a continuous outcome. Results are presented as estimated means over the $24 \mathrm{~h}$ period and standard error (SE). The number of desaturations is presented as mean number per hour and the area under the $80 \% \mathrm{SpO}_{2}$ limit as percentage per second. All models were adjusted for birth weight, GA, postnatal age at time of RBC transfusion, Ht value before $\mathrm{RBC}$ transfusion, respiratory support, and additional caffeine loading doses in $24 \mathrm{~h}$ prior to RBC transfusion. A two-sided $p$ value of $<0.05$ was considered statistically significant. Statistical analyses were performed using the computing environment R (v3.4.1, Inc., Boston, MA, USA) [27]. No imputation methods for missing data were applied.
Fig. 1 Schematic figure of the number of desaturations and area under the curve (AUC) below a saturation limit of $80 \%$. A desaturation was defined as a saturation level below $80 \%$ for a second or longer. The area under the $80 \% \mathrm{SpO}_{2}$ limit (AUC) was calculated by multiplying the duration (second) by the depth $(\%)$ of a desaturation

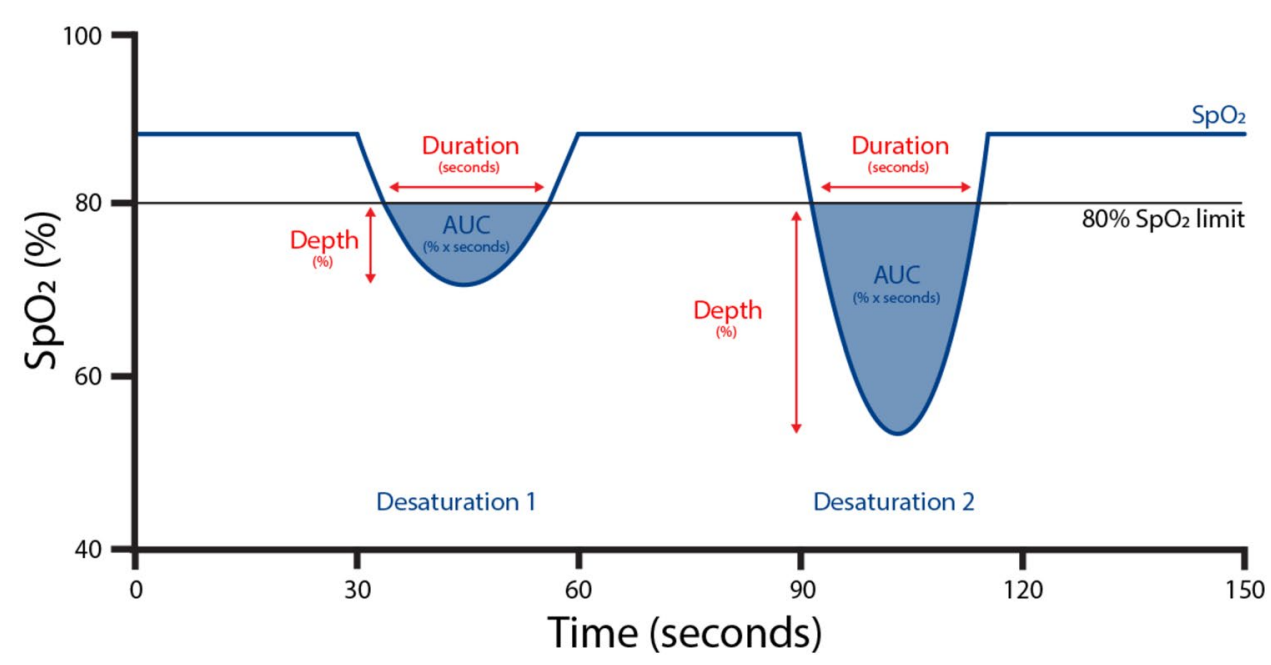


Fig. 2 Exclusion of non-eligible preterm infants and red blood cell $(\mathrm{RBC})$ transfusions

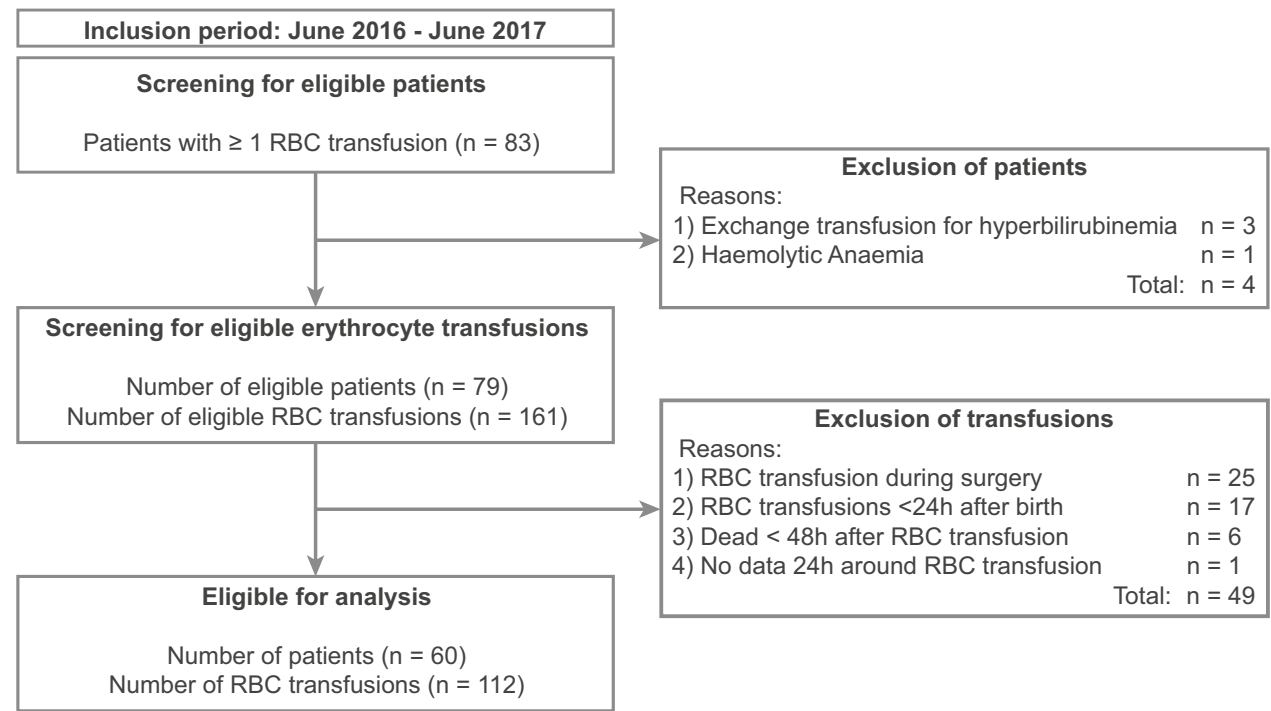

\section{Results}

Eighty-three preterm infants received at least one RBC transfusion. After exclusion of non-eligible patients and transfusions, data of 60 infants with a total of 112 RBC transfusions were included in the analysis (Fig. 2), of which 47/112 (42\%) were first RBC transfusions. The median GA was 26.7 [25.6-29.0] weeks; the median birth weight was 825 [708-959] g (Table 1). During NICU admission, the infants received a median of 2 [1-3] RBC transfusions with a median administered blood volume of 15 [12-18] ml per transfusion. The median postnatal age at RBC transfusion was $19.5[10.8-29.0]$ days.

\section{Number of desaturations and area under the $80 \%$ $\mathrm{SpO}_{2}$ limit}

Overall, the number of desaturations per hour in the $24 \mathrm{~h}$ before transfusion decreased from mean (SE) $3.28(0.55)$ to $2.25(0.38)$ in the $24 \mathrm{~h}$ after transfusion $(p<0.001)$ (Table 2). The area under the $80 \% \mathrm{SpO}_{2}$ limit decreased from $0.14(0.04)$ to $0.08(0.02) \% / \mathrm{s}$ in all RBC transfusions $(p=0.02)$. The decrease in the number of desaturations and the area under the $80 \% \mathrm{SpO}_{2}$ limit was most prominently in those with higher mean desaturations (Fig. 3a-d). In contrast to the area under the $80 \% \mathrm{SpO}_{2}$ limit, the number of desaturations decreased significantly in all GA subgroups and $\mathrm{Ht}$ subgroups (Table 2). The number of desaturations decreased significantly in both the invasive and the non-invasive respiratory support groups, whereas the area under the $80 \% \mathrm{SpO}_{2}$ limit decreased significantly only in the invasive respiratory support group (Supplemental Fig. 1a, b; Table 2).

On an individual level, the number of desaturations decreased in $12 / 25$ (48.0\%) of RBC transfusions with desaturations $\leq 1$, in $16 / 28(57.1 \%)$ of transfusions with desaturations $1-3$, in $19 / 24$ (79.2\%) of transfusions with desaturation 3-6, and in 30/35 (85.7\%) of transfusions with desaturations $\geq 6$ (Fig. 4a). The area under the $80 \% \mathrm{SpO}_{2}$ limit decreased in 13/25 (52.0\%) of RBC transfusions with desaturations $\leq 1$, in $18 / 28(64.3 \%)$ of transfusions with desaturations $1-3$, in $17 / 24(70.8 \%)$ of transfusions with desaturation 3-6, and in 28/35 (80.0\%) of transfusions with desaturations $\geq 6$ (Fig. $4 \mathrm{~b}$ ). The higher the mean number of desaturations in the $24 \mathrm{~h}$ prior to RBC transfusion, the higher the decrease in the number of desaturations after RBC transfusion (Fig. 4a).

\section{Respiratory parameters}

In the overall group, the $\mathrm{SpO}_{2}$ in the $24 \mathrm{~h}$ before $\mathrm{RBC}$ transfusion differed not significantly from that in the $24 \mathrm{~h}$ after RBC transfusion $(p=0.97)$ (Fig. 5a). The $\mathrm{FiO}_{2}$ slightly increased before RBC transfusion and decreased after transfusion, although not statistically significant $(p=0.07)$ (Fig. 5b). Overall, the respiratory rate was not significantly influenced by RBC transfusion $(p=0.29)$ (Fig. 5f). 
Table 1 Demographics and clinical characteristics of the study population

\begin{tabular}{|c|c|c|c|}
\hline & Characteristics & $N$ & \\
\hline \multirow[t]{16}{*}{ Patients $(N=60)$} & Female gender & 60 & $19(31.1 \%)$ \\
\hline & Gestational age at birth, weeks & 60 & $26.7[25.6-29.0]$ \\
\hline & Birth weight, grams & 60 & 825 [708-959] \\
\hline & SGA & 60 & $19(31.7 \%)$ \\
\hline & Cesarean section & 60 & $36(60.0 \%)$ \\
\hline & Singleton & 60 & $46(76.7 \%)$ \\
\hline & NEC & 60 & $8(13.3 \%)$ \\
\hline & Septic episode during admission & 60 & $35(59.3 \%)$ \\
\hline & PDA & 60 & $44(73.3 \%)$ \\
\hline & RDS & 60 & $58(96.7 \%)$ \\
\hline & $\mathrm{BPD}$ & 51 & $31(60.8 \%)$ \\
\hline & IVH & 60 & $14(23.3 \%)$ \\
\hline & Mortality & 60 & $10(16.7 \%)$ \\
\hline & Number of erythrocyte transfusions & 60 & $2[1-3]$ \\
\hline & Days on invasive mechanical ventilation & 60 & 9 [4-17] \\
\hline & Total days of respiratory support & 52 & 72 [42-93] \\
\hline \multirow[t]{20}{*}{ Transfusions $(N=112)$} & Number of RBC transfusion & & \\
\hline & 1st RBC transfusion & 112 & $47(42 \%)$ \\
\hline & 2nd RBC transfusion & 112 & $30(27 \%)$ \\
\hline & 3th $\mathrm{RBC}$ transfusion & 112 & $17(15 \%)$ \\
\hline & $\geq 4$ th $\mathrm{RBC}$ transfusion & 112 & $18(16 \%)$ \\
\hline & Postnatal age, days, at transfusion & 112 & $19.5[10.8-29.0]$ \\
\hline & Hemoglobin, $\mathrm{mmol} / \mathrm{L}$, before transfusion & 110 & $5.9[5.5-6.8]$ \\
\hline & Hematocrit, $\%$, before transfusion & 112 & 27 [25-29] \\
\hline & $\mathrm{PaO} 2, \mathrm{kPa}$, before transfusion & 103 & $5.1[4.2-7.4]$ \\
\hline & $\mathrm{PaCO} 2, \mathrm{kPa}$, before transfusion & 109 & $7.2[6.4-8.2]$ \\
\hline & According to local transfusion guideline & 112 & $98(88 \%)$ \\
\hline & Active bleeding & 112 & $2(2 \%)$ \\
\hline & Iron supplementation, at transfusion & 112 & $24(21 \%)$ \\
\hline & Administered volume of blood, $\mathrm{ml}$ & 110 & $15.0[12.0-18.0]$ \\
\hline & Respiratory support during $\mathrm{RBC}$ transfusion & 112 & \\
\hline & Invasive respiratory support & & $74(66 \%)$ \\
\hline & Non-invasive respiratory support & & $38(34 \%)$ \\
\hline & Caffeine therapy & 112 & $107(96 \%)$ \\
\hline & Loading dose $24 \mathrm{~h}$ before transfusion & 112 & $16(14 \%)$ \\
\hline & Time before transfusion, hours & 16 & $8.0[5.9-9.3]$ \\
\hline
\end{tabular}

Values are expressed as median [IQR] or number (\%); SGA, small for gestational age; $N E C$, necrotizing enterocolitis; $P D A$, patent ductus arteriosus; $R D S$, respiratory distress syndrome; $B P D$, bronchopulmonary dysplasia; $I V H$, intraventricular hemorrhage; $R B C$ transfusion, red blood cell transfusion

\section{Circulatory parameters}

The median heart rate increased in the first hours after RBC transfusion and then decreased below the median heart rate pre-transfusion (Fig. 5c). However, the estimated mean heart rate in the $24 \mathrm{~h}$ before and after transfusion did not differ significantly $(p=0.89)$. The mean perfusion index increased from $1.05(0.05)$ to $1.18(0.05)$ after RBC transfusion in all RBC transfusions $(p<0.001)$ (Fig. 5e). The mean arterial blood pressure increased from 28.5 (3.9) to 33.5 (3.4) $\mathrm{mmHg}$ after $\mathrm{RBC}$ transfusion, although not statistically significant $(p=0.09)$ (Fig. 5d).

\section{Discussion}

This study gives insight in the effects of RBC transfusions on the number of desaturations and the area under the $80 \%$ $\mathrm{SpO}_{2}$ limit derived from respiratory monitor data. Both the 
Table 2 Before and after red blood cell transfusion comparisons in the number of desaturations and the area under $80 \% \mathrm{SpO}_{2}$ limit

\begin{tabular}{|c|c|c|c|c|c|}
\hline Subgroup & & Outcome & Pre-RBC transfusion & Post-RBC transfusion & $p$ value \\
\hline \multirow[t]{2}{*}{ All RBC transfusions } & \multirow[t]{2}{*}{$N=112$} & Area $<80 \% \mathrm{SpO}_{2}$ limit & $0.14(0.04)$ & $0.08(0.02)$ & 0.02 \\
\hline & & No of desaturations & $3.28(0.55)$ & $2.25(0.38)$ & $<0.001$ \\
\hline \multirow[t]{8}{*}{ Number of desaturations ${ }^{a}$} & \multirow{2}{*}{$\begin{array}{l}<1 \\
N=25\end{array}$} & Area $<80 \% \mathrm{SpO}_{2}$ limit & $0.01(0.004)$ & $0.01(0.003)$ & 0.54 \\
\hline & & No of desaturations & $0.39(0.05)$ & $0.52(0.07)$ & $<0.001$ \\
\hline & \multirow{2}{*}{$\begin{array}{l}1-3 \\
N=28\end{array}$} & Area $<80 \% \mathrm{SpO}_{2}$ limit & $0.07(0.02)$ & $0.03(0.01)$ & 0.08 \\
\hline & & No of desaturations & $1.41(0.16)$ & $1.48(0.17)$ & 0.21 \\
\hline & \multirow{2}{*}{$\begin{array}{l}3-6 \\
N=24\end{array}$} & Area $<80 \% \mathrm{SpO}_{2}$ limit & $0.26(0.09)$ & $0.18(0.06)$ & 0.41 \\
\hline & & No of desaturations & $3.58(0.39)$ & $2.85(0.31)$ & $<0.001$ \\
\hline & \multirow{2}{*}{$\begin{array}{l}>6 \\
N=35\end{array}$} & Area $<80 \% \mathrm{SpO}_{2}$ limit & $0.46(0.13)$ & $0.20(0.06)$ & 0.04 \\
\hline & & No of desaturations & $7.5(0.66)$ & $4.26(0.38)$ & $<0.001$ \\
\hline \multirow[t]{6}{*}{ Gestational age } & \multirow{2}{*}{$\begin{array}{l}<26 \text { weeks } \\
N=50\end{array}$} & Area $<80 \% \mathrm{SpO}_{2}$ limit & $0.19(0.07)$ & $0.11(0.04)$ & 0.08 \\
\hline & & No of desaturations & $3.92(0.86)$ & $2.59(0.57)$ & $<0.001$ \\
\hline & \multirow{2}{*}{$\begin{array}{l}26-28 \text { weeks } \\
N=51\end{array}$} & Area $<80 \% \mathrm{SpO}_{2}$ limit & $0.16(0.05)$ & $0.12(0.04)$ & 0.32 \\
\hline & & No of desaturations & $3.92(0.71)$ & $2.97(0.54)$ & $<0.001$ \\
\hline & \multirow{2}{*}{$\begin{array}{l}\geq 28 \text { weeks } \\
N=11\end{array}$} & Area $<80 \% \mathrm{SpO}_{2}$ limit & $0.05(0.03)$ & $0.01(0.005)$ & 0.17 \\
\hline & & No of desaturations & $1.03(0.39)$ & $0.23(0.09)$ & 0.009 \\
\hline \multirow[t]{6}{*}{ Hematocrit } & \multirow{2}{*}{$\begin{array}{l}<25 \% \\
N=34\end{array}$} & Area $<80 \% \mathrm{SpO}_{2}$ limit & $0.15(0.06)$ & $0.08(0.03)$ & 0.12 \\
\hline & & No of desaturations & $3.53(0.72)$ & $2.08(0.42)$ & $<0.001$ \\
\hline & \multirow{2}{*}{$\begin{array}{l}25-30 \% \\
N=61\end{array}$} & Area $<80 \% \mathrm{SpO}_{2}$ limit & $0.12(0.04)$ & $0.07(0.02)$ & 0.08 \\
\hline & & No of desaturations & $2.83(0.54)$ & $2.21(0.42)$ & $<0.001$ \\
\hline & \multirow{2}{*}{$\begin{array}{l}\geq 30 \% \\
N=17\end{array}$} & Area $<80 \% \mathrm{SpO}_{2}$ limit & $0.19(0.07)$ & $0.11(0.04)$ & 0.26 \\
\hline & & No of desaturations & $3.47(1.01)$ & $2.23(0.65)$ & 0.001 \\
\hline \multirow[t]{3}{*}{ Respiratory support } & $\begin{array}{l}\text { Invasive } \\
N=74\end{array}$ & $\begin{array}{l}\text { Area }<80 \% \mathrm{SpO}_{2} \text { limit } \\
\text { No of desaturations }\end{array}$ & $\begin{array}{l}0.13(0.04) \\
2.12(0.37)\end{array}$ & $\begin{array}{l}0.07(0.02) \\
1.48(0.26)\end{array}$ & $\begin{aligned} & 0.03 \\
< & 0.001\end{aligned}$ \\
\hline & Non-invasive & Area $<80 \% \mathrm{SpO}_{2}$ limit & $0.15(0.06)$ & $0.09(0.04)$ & 0.19 \\
\hline & $N=37$ & No of desaturations & $4.47(0.92)$ & $3.01(0.62)$ & $<0.001$ \\
\hline
\end{tabular}

Data before and after red blood cell (RBC) transfusion are expressed as estimated means(SE). The area under the $80 \% \mathrm{SpO}_{2}$ curve is presented as mean $\% /$ second and the number of desaturations as mean number/hour. For both parameters, the mean is calculated over the $24 \mathrm{~h}$ period before and after transfusion

${ }^{a}$ Mean number of desaturations per hour in the $24 \mathrm{~h}$ before transfusion

number of desaturations and area under the $80 \% \mathrm{SpO}_{2}$ limit, and consequently the hypoxic burden, decreased after RBC transfusion. The higher the number of desaturations before a transfusion, the larger the effect. The number of desaturations decreased after transfusion, irrespective of the respiratory support type, Ht values, or GA at birth. For the area under the $80 \% \mathrm{SpO}_{2}$ limit, this effect was only observed in invasively ventilated infants. In those infants already had no desaturations prior to RBC transfusion, no beneficial effect could be objectified.

RBC transfusion guidelines are mostly based on $\mathrm{Hb}$ level cutoffs, and thresholds for transfusion vary largely amongst national guidelines and local NICUs [3]. Symptomatic anemia, however, does not occur at a predefined $\mathrm{Hb}$ level [28]. In our study, RBC transfusion had a positive effect on the number of desaturations, especially in those experiencing the most desaturations before transfusion. Similarly, a decrease in intermittent hypoxia and apneas after RBC transfusion was found in previous studies [6, 9, 29]. However, none of these studies stratified for the frequency of desaturations before transfusion. The decrease in the number of desaturations and the area under the $80 \%$ $\mathrm{SpO}_{2}$ after transfusion was found to be inconsistent in this study. Although the number of desaturations decreased significantly in almost all subgroups, the area under the $80 \% \mathrm{SpO}_{2}$ limit only decreased significantly in infants with the highest number of desaturations and invasive ventilation. This might indicate that the decrease in the occurrence of desaturations is possibly a decrease in the least severe desaturations.

Hypoxemic episodes are known to be associated with late death and disability in preterm infants [26]. A post hoc analysis of the premature infants in need of transfusion (PINT) trial suggested a cognitive deficit at 18-21 months in infants who were held at a lower hemoglobin level [30]. A recent systematic review also 
a.

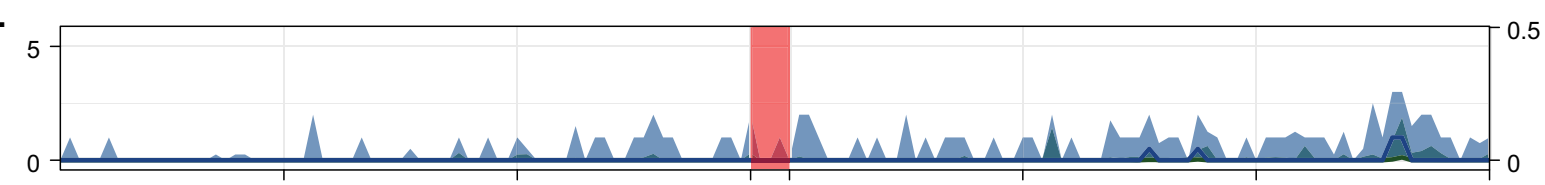

b.
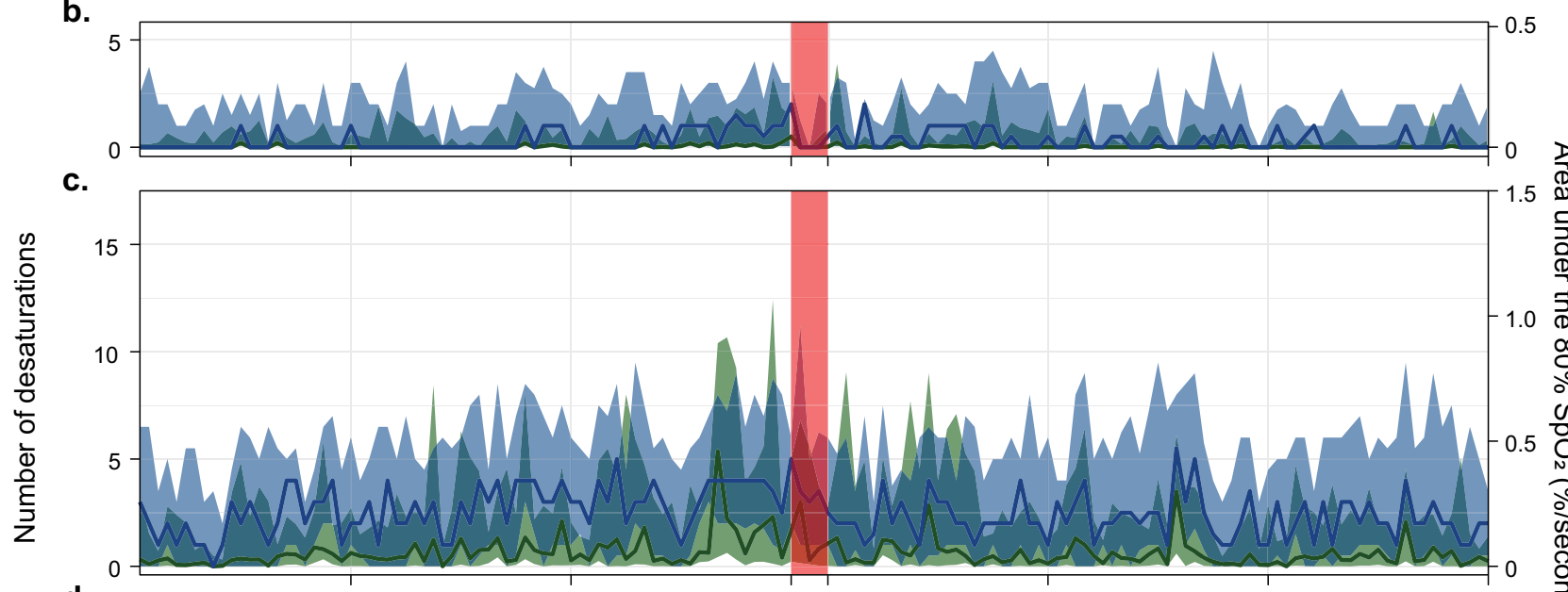

d.

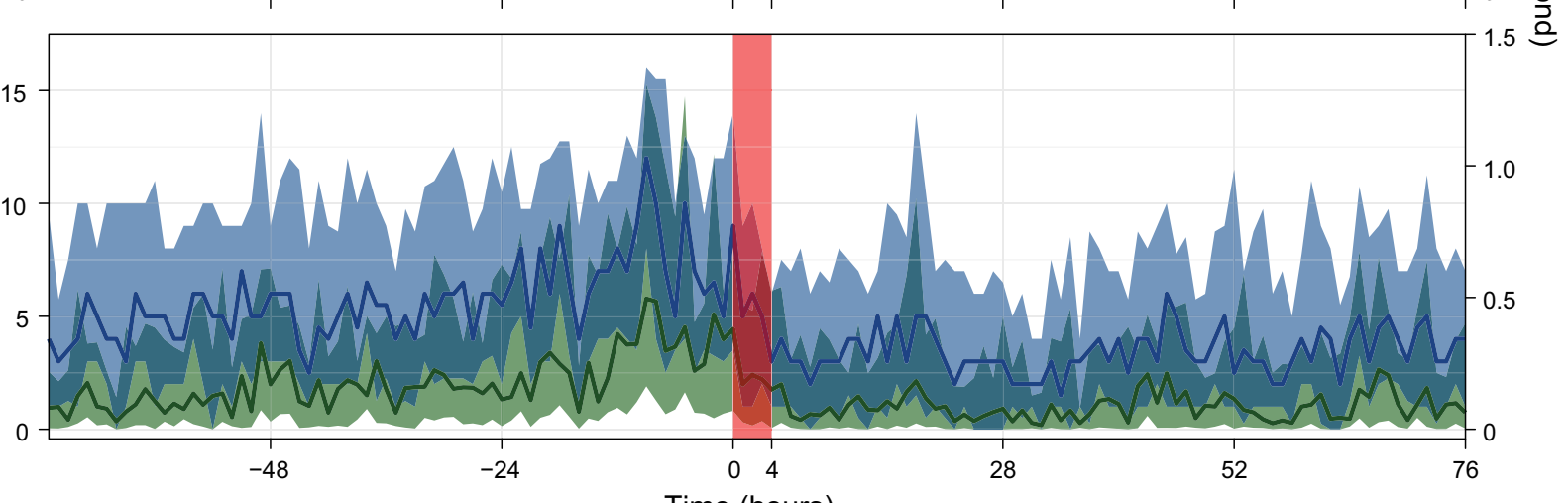

Time (hours)

Median (IQR) area under the $80 \% \mathrm{SpO}_{2}$ (\%/second)

Red blood cell (RBC) transfusion

Median (IQR) number of desaturation $<80 \%$ (number/hour)

Fig. 3 Graphs with data of the red blood cell (RBC) transfusions per desaturation subgroup, from 3 days before until 3 days after transfusion. The number of desaturations per hour on the left $y$-axis and the area under the $80 \%$ oxygen saturation on the right $y$-axis are

suggested that anemia and RBC transfusions have impact on the developing brain of preterm infants, possibly by the effect on cerebral oxygenation [31]. Causality of impaired neurodevelopment with hypoxemic episodes was, however, not confirmed by two recent RCTs comparing restrictive to liberal transfusion strategy $[18,19]$. These trials provided clinically relevant and meaningful information regarding the neurodevelopmental outcomes with different transfusion thresholds in large cohorts of preterm infants. The duration of respiratory support and age at last use of caffeine therapy as a measure of hypoxia were equal in both treatment groups. Other more subtle manifestations of hypoxia, such as apnea, were not displayed for RBC transfusions with mean number of desaturations in the $24 \mathrm{~h}$ prior to transfusion $\mathbf{a} \leq 1, \mathbf{b} 1-3$, c $3-6$, and $\mathbf{d} \geq 6$. Data are presented as median [interquartile range (IQR)] because of the skewed distribution

reported as this was not the main focus of the studies. Most importantly, the level of hypoxia before and the decrease after RBC transfusion were therefore also not reported and could differ between infants within a treatment group. Although speculative, RBC transfusion at a certain level of desaturations could decrease the hypoxic burden, irrespective of the degree of anemia, and consequently might prevent hypoxia-associated long-term adverse outcomes in preterm infants.

$\mathrm{RBC}$ transfusion, on the other hand, is not without risk. Although no advantageous outcomes of RBC transfusion are found on long-term mortality and severe morbidity [18, 19, 32-35], it is unknown whether more subtle long-term 
Fig. 4 Decrease in a the mean number of desaturations and b area under the $80 \%$ oxygen saturation $\left(\mathrm{SpO}_{2}\right)$ limit in the $24 \mathrm{~h}$ after red blood cell (RBC) transfusion in relation to the mean values in the $24 \mathrm{~h}$ before transfusion. Data are presented individually for all RBC transfusions, marked in the desaturation subgroups

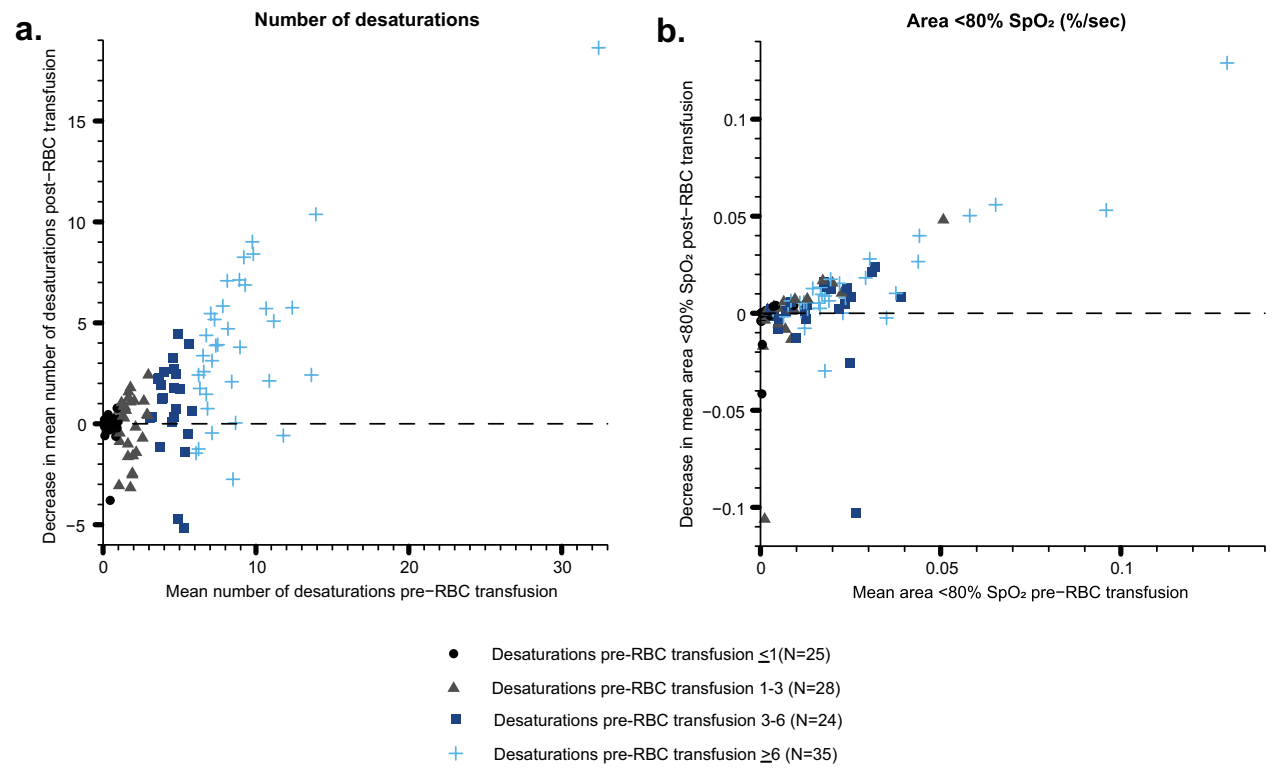

adverse effects of RBC transfusions itself occur in preterm infants. However, a previous study found negative associations with platelet transfusions, and we could argue that a blood transfusion leads to an immunologic and inflammatory response [36].

A reported inverse correlation between $\mathrm{Ht}$ values and the probability of future apneas suggests that the effect of RBC transfusion on apneas is mediated by increased oxygen transport capacity [29]. Apneas can be of central, obstructive, or mixed origin, which cannot be distinguished from the used respiratory data. RBC transfusion is likely not effective in case of obstructive apneas, and, although speculative, this could explain why hypoxia is not always reduced completely after transfusion in our study. Additionally, apneas and the related hypoxia in preterm infants are not specific for anemia only; these could be due to other neonatal diseases as well, such as pulmonary disease or sepsis.

Two-thirds of our study population were invasively ventilated during transfusion and were consequentially less likely to have desaturations. Also, the severity and etiology might differ from desaturations during non-invasive ventilation. In about a quarter of the transfusions during invasive respiratory support, no desaturations occurred before transfusion. When desaturations were present, the frequency decreased significantly after transfusion, which suggests that central apneas with desaturations might still occur during invasive ventilation. A previous study found improved oxygenation after RBC transfusion in mechanically ventilated preterm infants, although data on oxygenation was only collected at three time points [37]. For invasively ventilated infants, the number of desaturations only might not be sufficient to indicate the need for transfusion. $\mathrm{Ht}$ or $\mathrm{Hb}$ levels need to be evaluated before deciding on the need for RBC transfusion.

In our study population, the $\mathrm{FiO}_{2}$ was slightly increased during the day before transfusion, probably as a result of manual adjustments as response to an increase in desaturations. Clinicians might already have noticed the impaired oxygenation. The available data did not indicate alternations in the circulatory parameters before transfusion, suggesting that circulatory parameters do not indicate the need for transfusion. After RBC transfusion, median arterial blood pressure and pulse index increased immediately as a result of increased blood volume. Heart rate slightly increased in the first hours after transfusion, likely due to volume load, followed by a decrease below the average heart rate pre-transfusion.

A limitation of this study is that co-interventions such as respiratory support and caffeine therapy could have been intensified during transfusion to improve an infant's respiratory status. In 11 cases, invasive ventilation was started within $12 \mathrm{~h}$ before transfusion, and in 16 cases, an additional caffeine loading dose was administered in the $24 \mathrm{~h}$ prior to transfusion. In this study, the effect of $\mathrm{RBC}$ transfusion on the respiratory status was adjusted for these co-interventions in the mixed effects models. Additionally, we could not assess whether the presence of clinical signs, such as a pale skin, contributed to the decision to give a RBC transfusion, as clinical signs were likely underreported.

A more individualized approach would be key to optimize the risk benefit ratio of medical interventions such as RBC transfusions. The large availability of physiological monitor data enabled us to objectively detect 

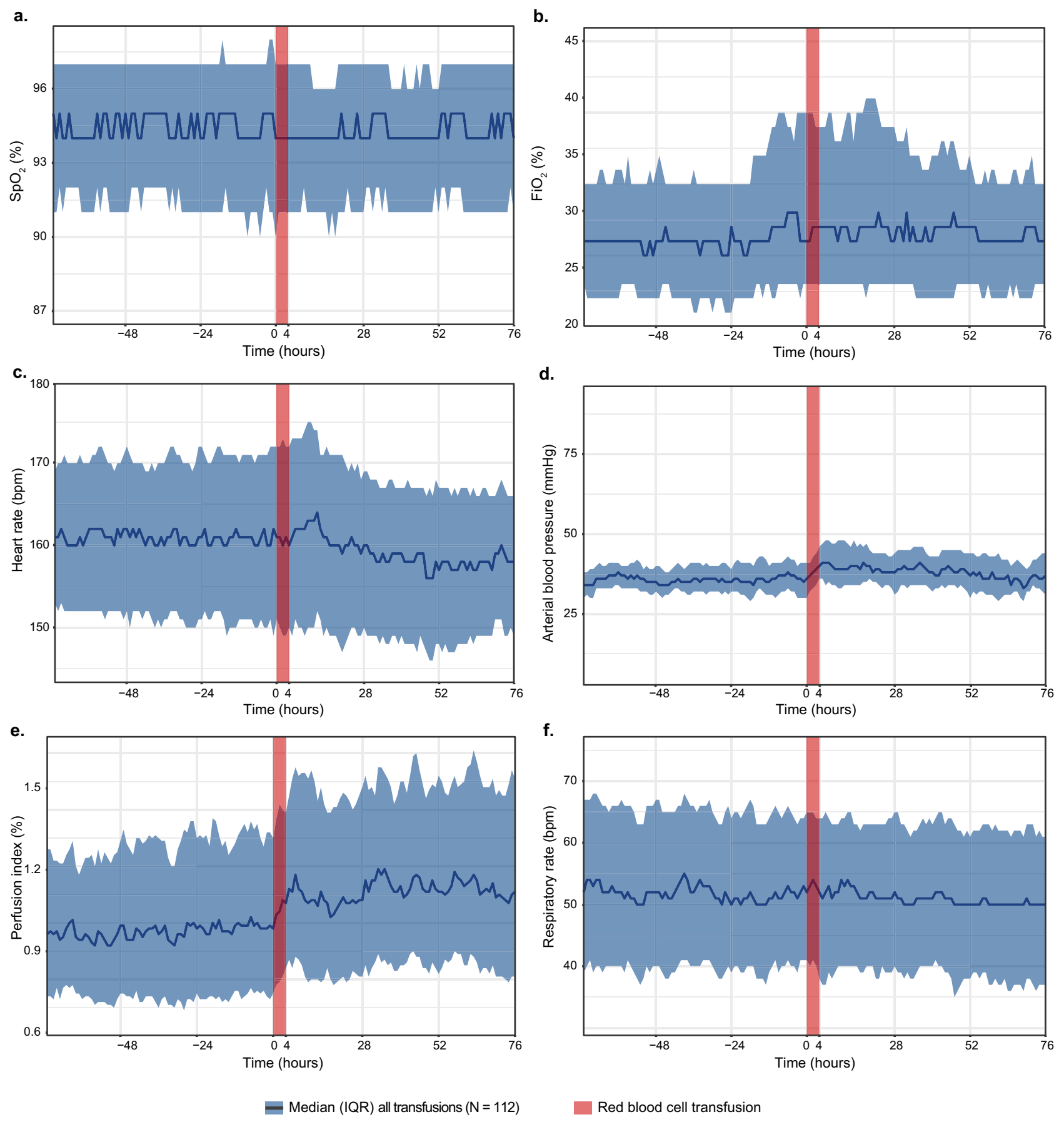

Fig. 5 Graphs with data of all red blood cell transfusions displayed over 3 days before until 3 days after transfusion; a oxygen saturation $\left(\mathrm{SpO}_{2}\right), \mathbf{b}$ fraction of inspired oxygen $\left(\mathrm{FiO}_{2}\right), \mathbf{c}$ heart rate $(\mathrm{bpm}), \mathbf{d}$

mean arterial blood pressure $(\mathrm{mmHg})$, e perfusion index $(\%)$, f respiratory rate $(\mathrm{bpm})$. Data are presented as median [interquartile range (IQR)] because of the skewed distribution

desaturations and hypoxia associated with anemia and to evaluate alterations in a patient's clinical status. Algorithms detecting relevant patterns in physiological monitor data could provide more individualized care and help predict which patients are most likely to benefit. Unnecessary

transfusions, with the risk for adverse effects, could then be avoided.

In conclusion, RBC transfusions could help decrease oxygen desaturations and the hypoxic burden in preterm newborns, especially when desaturations are more frequent 
prior to transfusion. Transfusion thresholds alone do not seem to indicate who will benefit from RBC transfusion. In future care, algorithms to detect relevant patterns in bedside cardiorespiratory monitor data can be used to predict which preterm infant will benefit from RBC transfusion.

Supplementary information The online version contains supplementary material available at https://doi.org/10.1007/s00431-021-04218-5.

Acknowledgements The authors thank Dr. J. Hagoort from the Department of Pediatric Surgery at Erasmus MC for carefully reading and editing the text.

Author contributions All authors made substantial contributions to the conception and design of the study. Jarinda Poppe, Tanja van Essen, and Willem van Weteringen extracted the data, and Jarinda Poppe, Tanja van Essen, Willem van Weteringen, Sten Willemsen, Sinno Simons, and Rogier de Jonge contributed to the data analysis and interpretation. Jarinda Poppe and Tanja van Essen wrote the first draft of the manuscript, and all authors revised the manuscript for intellectual content. All authors gave their final approval for publication of the manuscript and agreed to be accountable for all aspects of the work.

Availability of data and material The data that support the findings of this study are available from the corresponding author upon reasonable request.

\section{Declarations}

Ethics approval The local medical ethics review board waived approval for this study pursuant to the Dutch Medical Research Involving Human Subjects Act (MEC-2018-1106).

Conflict of interest The authors declare no competing interests.

Open Access This article is licensed under a Creative Commons Attribution 4.0 International License, which permits use, sharing, adaptation, distribution and reproduction in any medium or format, as long as you give appropriate credit to the original author(s) and the source, provide a link to the Creative Commons licence, and indicate if changes were made. The images or other third party material in this article are included in the article's Creative Commons licence, unless indicated otherwise in a credit line to the material. If material is not included in the article's Creative Commons licence and your intended use is not permitted by statutory regulation or exceeds the permitted use, you will need to obtain permission directly from the copyright holder. To view a copy of this licence, visit http://creativecommons.org/licenses/by/4.0/.

\section{References}

1. Keir AK, Yang J, Harrison A, Pelausa E, Shah PS, Canadian Neonatal N (2015) Temporal changes in blood product usage in preterm neonates born at less than 30 weeks' gestation in Canada. Transfusion 55:1340-1346

2. Kattwinkel J (1977) Neonatal apnea: pathogenesis and therapy. J Pediatr 90:342-347

3. Howarth C, Banerjee J, Aladangady N (2018) Red blood cell transfusion in preterm infants: current evidence and controversies. Neonatology 114:7-16
4. Chirico G (2014) Red blood cell transfusion in preterm neonates: current perspectives. Int J Clin Transfu Medic 21-28. https://doi. org/10.2147/IJCTM.S40026

5. Westkamp E, Soditt V, Adrian S, Bohnhorst B, Groneck P, Poets CF (2002) Blood transfusion in anemic infants with apnea of prematurity. Biol Neonate 82:228-232

6. Abu Jawdeh EG, Martin RJ, Dick TE, Walsh MC, Di Fiore JM (2014) The effect of red blood cell transfusion on intermittent hypoxemia in ELBW infants. J Perinatol 34:921-925

7. Bifano EM, Smith F, Borer J (1992) Relationship between determinants of oxygen delivery and respiratory abnormalities in preterm infants with anemia. J Pediatr 120:292-296

8. Kasat K, Hendricks-Munoz KD, Mally PV (2011) Neonatal red blood cell transfusions: searching for better guidelines. Blood Transfus 9:86-94

9. Kovatis KZ, Di Fiore JM, Martin RJ, Abbasi S, Chaundhary AS, Hoover S, Zhang Z, Kirpalani H (2020) Effect of blood transfusions on intermittent hypoxic episodes in a prospective study of very low birth weight infants. J Pediatr

10. Poets CF, Pauls U, Bohnhorst B (1997) Effect of blood transfusion on apnoea, bradycardia and hypoxaemia in preterm infants. Eur $\mathrm{J}$ Pediatr 156:311-316

11. Christensen RD (2012) Associations between "early" red blood cell transfusion and severe intraventricular hemorrhage, and between "late" red blood cell transfusion and necrotizing enterocolitis. Semin Perinatol 36:283-289

12. La Gamma EF, Blau J (2012) Transfusion-related acute gut injury: feeding, flora, flow, and barrier defense. Semin Perinatol 36:294-305

13. dos Santos AM, Guinsburg R, de Almeida MF, Procianoy RS, Leone CR, Marba ST, Rugolo LM, Fiori HH, Lopes JM, Martinez FE et al (2011) Red blood cell transfusions are independently associated with intra-hospital mortality in very low birth weight preterm infants. J Pediatr 159(371-376):e371-373

14. Baer VL, Lambert DK, Henry E, Snow GL, Christensen RD (2011) Red blood cell transfusion of preterm neonates with a grade 1 intraventricular hemorrhage is associated with extension to a Grade 3 or 4 hemorrhage. Transfusion 51:1933-1939

15. Lee EY, Kim SS, Park GY, Lee SH (2020) Effect of red blood cell transfusion on short-term outcomes in very low birth weight infants. Clin Exp Pediatr 63:56-62

16. D'Amato G, Faienza MF, Palladino V, Bianchi FP, Natale MP, Christensen RD, Giordano P, Del Vecchio A (2020) Red blood cell transfusions and potentially related morbidities in neonates under 32 weeks' gestation. Blood Transfus

17. Whyte R, Kirpalani H (2011) Low versus high haemoglobin concentration threshold for blood transfusion for preventing morbidity and mortality in very low birth weight infants. Cochrane Database of Systematic Reviews

18. Franz AR, Engel C, Bassler D, Rudiger M, Thome UH, Maier RF, Krageloh-Mann I, Kron M, Essers J, Buhrer C et al (2020) Effects of liberal vs restrictive transfusion thresholds on survival and neurocognitive outcomes in extremely low-birth-weight infants: the ETTNO randomized clinical trial. JAMA 324:560-570

19. Kirpalani H, Bell EF, Hintz SR, Tan S, Schmidt B, Chaudhary AS, Johnson KJ, Crawford MM, Newman JE, Vohr BR et al (2020) Higher or lower hemoglobin transfusion thresholds for preterm infants. N Engl J Med 383:2639-2651

20. Wardle SP, Garr R, Yoxall CW, Weindling AM (2002) A pilot randomised controlled trial of peripheral fractional oxygen extraction to guide blood transfusions in preterm infants. Arch Dis Child Fetal Neonatal Ed 86:F22-27

21. Whitehead HV, Vesoulis ZA, Maheshwari A, Rao R, Mathur AM (2018) Anemia of prematurity and cerebral near-infrared spectroscopy: should transfusion thresholds in preterm infants be revised? J Perinatol 38:1022-1029 
22. Izraeli S, Ben-Sira L, Harell D, Naor N, Ballin A, Davidson S (1993) Lactic acid as a predictor for erythrocyte transfusion in healthy preterm infants with anemia of prematurity. J Pediatr 122:629-631

23. Tschirch E, Weber B, Koehne P, Guthmann F, von Gise A, Wauer RR, Rudiger M (2009) Vascular endothelial growth factor as marker for tissue hypoxia and transfusion need in anemic infants: a prospective clinical study. Pediatrics 123:784-790

24. Guillen U, Cummings JJ, Bell EF, Hosono S, Frantz AR, Maier RF, Whyte RK, Boyle E, Vento M, Widness JA et al (2012) International survey of transfusion practices for extremely premature infants. Semin Perinatol 36:244-247

25. Fenton TR, Kim JH (2013) A systematic review and meta-analysis to revise the Fenton growth chart for preterm infants. BMC Pediatr 13:59

26. Poets CF, Roberts RS, Schmidt B, Whyte RK, Asztalos EV, Bader D, Bairam A, Moddemann D, Peliowski A, Rabi Y et al (2015) Association between intermittent hypoxemia or bradycardia and late death or disability in extremely preterm infants. JAMA 314:595-603

27. Team RC (2017) R: A language and environment for statistical computing. R Foundation for Statistical Computing. Vienna, Austria

28. Alverson DC (1995) The physiologic impact of anemia in the neonate. Clin Perinatol 22:609-625

29. Zagol K, Lake DE, Vergales B, Moorman ME, Paget-Brown A, Lee H, Rusin CG, Delos JB, Clark MT, Moorman JR et al. (2012) Anemia, apnea of prematurity, and blood transfusions. J Pediatr 161:417-421 e411

30. Whyte RK, Kirpalani H, Asztalos EV, Andersen C, Blajchman M, Heddle N, LaCorte M, Robertson CM, Clarke MC, Vincer MJ et al (2009) Neurodevelopmental outcome of extremely low birth weight infants randomly assigned to restrictive or liberal hemoglobin thresholds for blood transfusion. Pediatrics 123:207-213
31. Kalteren WS, Verhagen EA, Mintzer JP, Bos AF, Kooi EMW (2021) Anemia and red blood cell transfusions, cerebral oxygenation, brain injury and development, and neurodevelopmental outcome in preterm infants: a systematic review. Frontiers in Pediatrics 9:132

32. Connelly RJ, Stone SH, Whyte RK (1998) Early vs. late red cell transfusion in low birth weight infants 986 . Pediatr Res 43:170-170

33. Bell EF, Strauss RG, Widness JA, Mahoney LT, Mock DM, Seward VJ, Cress GA, Johnson KJ, Kromer IJ, Zimmerman MB (2005) Randomized trial of liberal versus restrictive guidelines for red blood cell transfusion in preterm infants. Pediatrics 115:1685-1691

34. Kirpalani H, Whyte RK, Andersen C, Asztalos EV, Heddle N, Blajchman MA, Peliowski A, Rios A, LaCorte M, Connelly R et al (2006) The premature infants in need of transfusion (PINT) study: a randomized, controlled trial of a restrictive (low) versus liberal (high) transfusion threshold for extremely low birth weight infants. J Pediatr 149:301-307

35. Chen HL, Tseng HI, Lu CC, Yang SN, Fan HC, Yang RC (2009) Effect of blood transfusions on the outcome of very low body weight preterm infants under two different transfusion criteria. Pediatr Neonatol 50:110-116

36. Curley A, Stanworth SJ, Willoughby K, Fustolo-Gunnink SF, Venkatesh V, Hudson C, Deary A, Hodge R, Hopkins V, Lopez Santamaria B et al (2019) Randomized trial of platelet-transfusion thresholds in neonates. N Engl J Med 380:242-251

37. James L, Greenough A, Naik S (1997) The effect of blood transfusion on oxygenation in premature ventilated neonates. Eur $\mathbf{J}$ Pediatr 156:139-141

Publisher's Note Springer Nature remains neutral with regard to jurisdictional claims in published maps and institutional affiliations.

\section{Authors and Affiliations}

\section{Jarinda A. Poppe ${ }^{1}$ (D) Tanja van Essen ${ }^{1} \cdot$ Willem van Weteringen $^{1,2} \cdot$ Sten P. Willemsen ${ }^{1,3} \cdot$ Irwin K. M. Reiss $^{1}$. Sinno H. P. Simons ${ }^{1} \cdot$ Rogier C. J. de Jonge ${ }^{4}$}

Tanja van Essen

t.vanessen@erasmusmc.nl

Willem van Weteringen

w.vanweteringen@erasmusmc.nl

Sten P. Willemsen

s.willemsen@erasmusmc.nl

Irwin K. M. Reiss

i.reiss@erasmusmc.nl

Sinno H. P. Simons

s.simons@erasmusmc.nl
Rogier C. J. de Jonge

r.c.j.dejonge@erasmusmc.nl

1 Department of Pediatrics, Division of Neonatology, Erasmus MC Sophia Children's Hospital, University Medical Center Rotterdam, Rotterdam, Netherlands

2 Department of Pediatric Surgery, Erasmus MC Sophia Children's Hospital, University Medical Center Rotterdam, Rotterdam, Netherlands

3 Department of Biostatistics, Erasmus MC, Erasmus University Medical Center, Rotterdam, Netherlands 
4 Pediatric Intensive Care Unit, Department of Pediatrics and Pediatric Surgery, Erasmus MC Sophia Children's
Hospital, University Medical Center Rotterdam, Rotterdam, Netherlands 